\title{
12
}

\section{Retrospect: Reflections on the Amherst Embassy}

Amherst and his embassy have not been judged kindly by history. ${ }^{1}$ The causes and the goals of the embassy have been lost in the scholarly debate over Amherst's failure to appear before the Jiaqing emperor as a result of refusing to kowtow. Amherst's own performance has been viewed as lacklustre, even inept, indecisive and overly cautious, and captive to the uncompromising pro-Company views of Staunton. ${ }^{2}$ The embassy has been described as not merely a failure but 'a fiasco' (Tuck, 2000, p. viii) and compared unfavourably with its predecessor the Macartney Embassy, although both failed to achieve their objectives (Platt, 2018, pp. 159-177). Both implicitly and explicitly, Amherst has been apportioned a substantial part of the blame for the mission's failure.

Amherst has been judged unfairly. The embassy did not fail because of his leadership or as a result of his final decision not to kowtow. Amherst was not a great leader by any measure, but he was a competent one

1 Douglas Peers wrote in his entry on Amherst in The Oxford Dictionary of National Biography, 'Neither historians nor his contemporaries and successors have been kind to Amherst; John Malcolm wrote of him that he was being compared to "the person who brought the blue flies into the butcher's shop"'. This refers to his later appointment as governor-general of Bengal. The dictionary also referred to Amherst admitting to Lord Morley, 'I would not have you suppose that I deem myself a man of sufficient calibre to govern India in difficult times'. In both China and later in India, he faced very difficult situations not of his own making and coped admirably under extreme pressure, eventually being vindicated for his decisions in India and leadership choices.

2 Gao (2016) wrote, for example, 'Amherst had to yield to Staunton's "experience-based" assessment of the situation' (p. 610). 
whose style was low key but effective. ${ }^{3}$ He was charming and his strong personal qualities of honesty and integrity stood him in good stead with his colleagues. He was focused on the major issues and engaged in their resolution at all the stages of the embassy. As the record shows, he kept up the morale of the party throughout a long and trying voyage and a very difficult journey through China, especially in the period before and immediately after Yuanmingyuan. He was clearly respected as a man and as a leader who was considerate, even tempered, good humoured and fair-minded, and who set an example to his men by his own behaviour. ${ }^{4} \mathrm{He}$ was very capable but not intellectually superior, wrote competently but without flair, and was considered a decent man. Under the most difficult of circumstances, the party never split into factions, nor was the leadership group marked by jealousy or rivalry. ${ }^{5}$ Amherst's leadership style won him loyalty as he was consultative and inclusive, balanced in his judgements, hardworking and approachable. Despite criticism to the contrary, Amherst was calm under pressure and comfortable making decisions, usually having first canvassed the views of his colleagues. Ultimately, the record shows he took full responsibility for his decisions. Throughout the whole enterprise, Amherst was a very steady hand on the tiller.

Both the Chinese and British thought of themselves as exceptional-each being utterly convinced of their own superiority — and found little to admire or emulate in the other. A major difference was that the British, as an emerging maritime-based empire that was global in nature, were keen to learn as much as they could about the Chinese political and commercial systems and decision-making in order to better exploit the

3 Canning wrote of him on his appointment as governor-general of Bengal in 1822, 'the appointment ... is not a very strong one; but ... Amherst is at least blameless. He is in good political principles; a Government man without implicitness and a courtier without subserviency' (Canning to Huskisson as quoted in Philips, 1940, p. 239, emphasis in original).

4 Amherst's friends spoke highly of his character. Lord Sidmouth summed these up in a letter dated 31 December 1815: 'I have no doubt of the success of the Embassy, upon the judgment, temper and address of the Person, in whose hands this important entity is fortunately placed' (in BL IOR MSS EUR F 140/35).

5 Eastberg (2009, p. 217, fn. 560), in her chapter on British debate on China and Lord Napier's appointment as the chief superintendent of British trade to China in 1834, mistakenly ascribed Lord Napier's dislike of Staunton to Amherst. Eastberg wrote, 'No love was lost between Napier and Staunton. According to Priscilla Napier [1995, p. 82], Amherst recorded in his notes from his studies in preparation for his mission that Staunton "may be deeply versed in Chinese literature ... but in politics his [sic] a Driveller"'. A review of Amherst's notes revealed no mention of Staunton, and a close reading of Priscilla Napier (1995, p. 82) showed that these were Lord Napier's words, not Amherst's. Further, Amherst's notes were written in 1815 , before Staunton's subsequent political career. 
trading opportunities that China offered. In contrast, the Qing court, in the British view, still saw itself as presiding over the centre of the universe. The court was ignorant of foreign nations, especially those of Europe, and was not interested in better understanding the British, continuing to ascribe to them the role of a traditional vassal who had travelled from afar to pay tribute.

The period following the Macartney Embassy of 1793 saw a substantial growth in British knowledge of China. The accounts of earlier embassies were augmented by the observations of men like Staunton, Morrison and Davis whose scholarship, knowledge of Mandarin and practical experience of dealing with the Canton authorities represented a fundamental shift from the Macartney Embassy in the depth of British understanding about China.

With the benefit of hindsight, it is not difficult to identify where the Amherst Embassy failed; indeed, it is difficult to see how it could have been successful in achieving its objectives. From its conception, it was hostage to the legacy of the Macartney Embassy. The widely held British belief in the positive impact on the Qing court made by the Macartney Embassy, which suggested that any future British mission would be treated as a special case and not within the narrow confines of the tribute system, turned out to be a myth. Rather, it has been seen, the Jiaqing emperor was determined to reassert Qing ceremonial protocol and insist on proper observances in order to not create an awkward and unacceptable precedent.

Nonetheless, the legacy of the Macartney Embassy had an indirect but important impact on the Amherst Embassy's reading of China. Barrow's book, Travels in China, published in 1804, was especially influential, as has been seen, in shaping and influencing the views of China held by the senior members of the Amherst Embassy. All of them had read Barrow's book and several carried copies with them to China. Ellis, in particular, whose first published account of the embassy was accepted as the official record of the embassy, makes no secret of his indebtedness to Barrow. Staunton (1824) complained in his private account that Barrow and others of the Macartney Embassy had left him with little new to report on China: 'The comparative success of the former mission, and the interest and novelty of first discovery, are wanting on the present occasion' (p. 205). 
The remedies to the identified deficiencies of the Macartney Embassy, such as its lack of British linguists and local expertise on the inner workings of the Qing bureaucracy, were ironically to prove especially damaging. Although Staunton and Morrison were highly talented men and certainly had the required skills and attributes, they were both viewed with deep suspicion by the Qing court and the emperor, evidenced by the imperial edict received at Canton in January 1815 (Imperial edict, 8 January 1815). ${ }^{6}$ This was on account of their linguistic skills in Mandarin and, in the case of Staunton, his tough stance during the course of several disputes with the local authorities at Canton. Morrison was also the subject of concern; he had come to the attention of authorities for illegally teaching Mandarin at the British Factory, for illegally setting up a Chinese printing press at Macao, and for illegally translating and publishing Christian and other texts from English into Chinese, all of which were strictly forbidden under the Canton trading system. Foreigners, long viewed as a potential threat to the fabric of Chinese society and a source of political insecurity, were of particular concern during the Jiaqing emperor's reign due to assassination attempts on the emperor's life, internal rebellions and piracy in southern Chinese waters throughout the first decade of the nineteenth century. Moreover, because of their Company status, the members of the Amherst Embassy were viewed by the imperial court and mandarins as mere traders and not worthy of inclusion in a mission sent in the name of the British monarch (Morrison, 1820, p. 52).

Cranmer-Byng (1962) has concluded that the Macartney Embassy was doomed to fail 'from the very beginning' and 'never stood the slightest chance of success' (p. 34). This judgement is even more applicable to the Amherst Embassy where the burden of the Macartney Embassy precedent inevitably doomed it to fail. The Amherst Embassy's fate was effectively sealed at the imperial banquet held in Tianjin on 13 August 1817, only three days after Amherst arrived in northern China. There the issue of the kowtow was raised formally, the Chinese asserting that Macartney had performed the ceremony before the Qianlong emperor and that Amherst was required to do the same. This claim became impossible to refute when the Jiaqing emperor asserted that he had personally witnessed Macartney kowtowing to his father in a large yellow yurt in the Garden of the Ten Thousand Trees (Wanshuyuan) (Fu, 1966, vol. 1, p. 326). ${ }^{7}$ Ellis (1817),

6 Reference to Staunton as 'young and crafty' and as someone who was likely to 'make trouble' is made in Chapter 4 of this study.

7 This reception took place on 14 September 1793. 
it has been seen, noted on 23 August: 'With this imperial assertion before us, however false or erroneous, it will be difficult, in the event of a renewed discussion, to press the precedent of Macartney' (p. 154). Amherst subsequently wrote in his report to George Canning that Guanghui and Sulenge informed him at the time of the imperial banquet at Tianjin that, 'the late Emperor, tho' he had accepted Lord Macartney's European homage, had in fact disapproved of it, and that therefore, could not be made a precedent on any future occasion' (Amherst to George Canning, 12 February 1817, in BL IOR G/12/197 (Reel 2) F 226). Either way, Amherst was left with no room to manoeuvre. He either had to kowtow, or refuse to kowtow and face the full wrath of the emperor's displeasure. He chose the latter after weighing up the options of what would cause the least damage to the Crown and British interests. This wedging of Amherst on the question of the kowtow in the context of the Macartney precedent was a central cause for the failure of his embassy. Ellis (1817) described it as 'the rock upon which the Embassy was wrecked' (p. 227).

Gao (2016) has suggested that there was an 'inner kowtow controversy' among the members of the Amherst Embassy. This characterisation is not borne out by a detailed examination of the embassy's negotiations with the Qing court. It needs to be stated that no member of the embassy was attracted to the prostration ceremony nor proposed kowtowing for its own sake simply to please the Chinese, not least because compliance was not reciprocal nor based on any notion of equality. Those who were prepared to consider kowtowing only did so reluctantly as an expediency to achieve a stated objective for the embassy. All agreed that unless there was a return in the form of Chinese concessions then it was not worth considering further. The latter view was certainly the position of Amherst who held out the possibility of kowtowing until the very end of negotiations. His pre-departure instructions had been ambiguous, even contradictory, but permitted him to use his 'own discretion' if the success of the mission warranted it. Amherst had tried to make sense of his instructions, first by asserting the Macartney precedent (and offering to enhance it by kneeling and bowing three times), and when this approach failed, he kept open the possibility of kowtowing up until it became apparent that further negotiation was fruitless. He offered, like Macartney, to perform the full ceremony if a court official of equal status would kowtow before a portrait of the Prince Regent, or, if the emperor would supply a written commitment undertaking that any Chinese official appointed to the Court of St James's would kowtow before the British monarch. 
Ellis initially argued that refusal to comply with mere court ceremonial was not a sufficient reason to consign the embassy to certain failure, a position to which Amherst was prepared to give serious consideration. ${ }^{8}$ However, by the time Amherst made his final decision, Ellis had conceded his earlier position and stated that he readily deferred to the weight of Staunton's local knowledge and arguments against kowtowing. Acknowledging this stance, Ellis (1817) wrote:

Whatever may have been my private opinion ... of compliance with the Chinese ceremonial, I am not disposed to maintain any substantial advantage would have resulted from the mere reception of the Embassy. (p. 437)

It appears that Ellis may have had a personal financial motive for advocating compliance with the kowtow. He wrote that while some members of 'our crew' may have rejoiced in Amherst's refusal to kowtow:

[For] my part, as I undertook the voyage to these distant seas more for profit than reputation I cannot but regret that I have lost the opportunity of bringing my venture to the market. (p. 227)

Ellis's admission drew a sharp rebuke from Barrow (1817a), who wrote in the Quarterly Review that 'the value of his opinion [on the kowtow] is greatly diminished by a candid, though we think rather indiscreet, avowal' that he had private business interests riding on the outcome of the embassy (p. 477). Ellis did not elaborate on the nature of his 'venture', but it likely involved the importation into China of some form of British manufactures or other products. ${ }^{9}$ Ellis did admit later on occasions throughout his subsequent career that he believed complying with court protocol might have given the embassy a better chance of success but made no attempt to substantiate this claim in any meaningful way ('Note' attached to Ellis, 1830, pp. 63-64). ${ }^{10}$ Amherst's final decision against kowtowing came down to the fact that, in the end, he could not satisfy

8 This, as seen in Chapter 10, was also Napoleon's view.

9 Staunton had been involved in an unsuccessful business venture in 1811 importing 'Salisbury flannels' into Canton, but the Chinese merchants offered only half the cost (Staunton Letters, 9 February 1811).

10 Ellis wrote, 'I have never seen reason to change the opinion ... that no success could attend the mission, without complying with the particular usages of the Chinese court'. He qualified his decision by emphasising that this view referred to the kowtow 'in the presence of the Emperor'. 
himself that it would guarantee obtaining the principle objectives of the embassy or would open a dialogue with the emperor or his senior ministers on these objectives.

Tuck's (2000) account of the embassy, as has been noted, is the most comprehensive analysis of the mission, but his conclusions are ambiguous. He argued that Amherst was planning to perform the kowtow after receiving an assurance from Heshitai that he would be a friend and advocate of the British at the Qing court on the condition that he performed the ceremony. However, Amherst changed his mind after consulting with Staunton, leading to the embassy's failure and Tuck's assessment that Staunton was to blame for the outcome. Tuck argued that, had Amherst agreed to kowtow, an imperial reception or 'the formal encounter, would almost certainly have passed off successfully' (p. xxxv). But he never explained what he meant by 'successfully' and proceeded to contradict himself in his conclusion when he added:

However, even if the audience had taken place, it is unlikely, despite ... Ho's [Heshitai's] ambiguous promise to help, that Amherst's negotiating proposals would have received any more sympathetic hearing than the requests made by Lord Macartney, which had been summarily rejected twenty-two years before. (p. xxxv)

Staunton immediately understood the nature of Heshitai's 'ambiguous promises. He recognised that the mere reception of the embassy before the emperor would not have resulted in any subsequent opportunity for negotiation of British goals, thereby rendering any such reception as meaningless in practical terms. His views were validated on receipt of the official Outline of the Ceremonies to be observed by the British ambassador where it was proposed that numerous kowtows be performed and that, at best, the emperor would be seen only from a distance.

While Amherst was swayed by Heshitai's promise, which formed the basis of his initial intention to kowtow, Staunton immediately saw through the mandarin's largesse. Staunton's judgement was based on a number of factors. The first arose from his ability to understand Mandarin and 'having heard, in the original language' Heshitai's 'utterances' (Staunton, 1824, p. 100). Staunton related that Heshitai's displeasure was never far from the surface. Second, Staunton's views were influenced heavily by the series of personal threats made towards him by the Qing court and his awareness of the Qing court's declared suspicion of him. Finally, the court's persistent assertion that Macartney had kowtowed in 1793, 
a proposition strenuously denied by the British, served to confirm to them that the Qing court was lying and could not be trusted. Staunton put forward his conclusions in a minute dated 18 January 1817 in which he declared that Heshitai's motives of assistance were 'easily disposed of':

They were not voluntary given but elicited by our own remarks. They proceeded from a man, who was evidently extremely anxious as well as personally interested to gain his point, a point which he had previously tried to accomplish by intimidating and gross insults without effect-(for instance ... asserting loudly that the Emperor was the Sovereign of all Nations, and threatening our immediate dismissal if we persevered in refusing to perform a ceremony, which the Emperor in that character required from us). [Heshitai's promises] were ... in themselves vague, inconclusive, and unworthy of credit, being merely confined to assurance of a gracious reception, the ungracious nature of which we already could pretty well anticipate from information gained from other quarters, and to his promises of personal aid and friendship in the subsequent furtherance of our views, promises which it was easy to make and still more easy to violate. (Staunton Minute dated 18 January 1817 in Morse, 1926/1966, vol. 3, p. 303, emphasis in original)

Staunton opposed performing the kowtow for several reasons. The act of obeisance was not mere court ceremonial but, rather, an act of the utmost significance: an act of homage that, under the tribute system, relegated the practitioner to vassal status and his sovereign to an inferior status below the Chinese emperor. On this point, he was strongly supported subsequently by Morrison. ${ }^{11}$ Equally, while performing the kowtow might secure an audience with the emperor, it did not guarantee that a positive outcome would follow, as Amherst learned after his expulsion. ${ }^{12}$ Once relegated to vassal status, the holding of negotiations would be impossible; negotiations implied equal status and the Chinese did not negotiate with vassals.

11 'Those nations of Europe who consider themselves tributary and yielding homage to China, should perform the ceremony' (Morrison, 1820, p. 9). Morrison objected particularly to the lack of reciprocity in the ceremony and its 'interference with the idea of equality'.

12 See Appendix F for the proposed final court ceremony signifying the conclusion of Amherst's mission, after which he was to leave Peking. 
In Staunton's view, a British ambassador's performance of the kowtow would adversely affect not only the hard-won status enjoyed by the Company representatives at Canton, but also would have profound implications for the future of British standing in China, as well as undermining the achievements of the Macartney Embassy 23 years earlier. The effects on British relations with China resulting from a 'submission to intimidation', Staunton felt, would be 'certain and permanent' (Staunton Minute dated 18 January 1817 in Morse, 1926/1966, vol. 3, p. 304, Appendix 5). Ultimately, Staunton (1822, p. 150) blamed the 'precipitate dismissal' of the embassy on the 'peculiarly untoward character' of the Jiaqing emperor. Amherst's sound judgement, thought Staunton (1822, p. 71), not only maintained British honour and promoted British commercial interests, but also ensured that 'Our character as the subjects of a free and independent state, has remained unsullied and entire'.

Amherst's record shows that he consulted with the senior members of his suite throughout the mission and formally sought their views both on arrival off Dagu and before making a final decision not to kowtow at Tongzhou. Some have criticised these consultations as weakness on Amherst's part, but it was clearly good leadership practice because, in the end, he was always going to be the one who had the responsibility for the final decision. It was only Amherst who had to perform the prostration ceremony, and it would be his name that would go down in infamy as the first British ambassador to kowtow before the Celestials. As a courtier at the Court of St James's for much of his earlier career, and as the bearer of a famous military name in Britain, these must have been considerations that weighed heavily on his reaching a final decision, knowing as he did that it would almost certainly lead to his expulsion from Peking.

Those who have sought to blame Staunton's influence for the decision not to kowtow have underestimated Amherst. Although Amherst was impressed initially by Ambassador Ismailof's compromise in which a single kowtow before the Kangxi emperor had led to a long stay and some concessions, he had come to realise by the time he made his final decision at Tongzhou that this option would not be entertained. Moreover, he had come to the conclusion that he could not trust his Chinese interlocutors and could not be reassured that kowtowing would lead to any positive outcomes for the embassy. Staunton's arguments and the example of the Dutch embassy of 1795, which had left empty handed despite kowtowing on every occasion when required, were no doubt considered and evaluated. Amherst acknowledged the importance of Staunton's views 
and opinions and thanked him in a letter five years later (Staunton, 1822, p. 68). Accordingly, in the end, Amherst followed the Prince Regent's instructions where he was to refer 'on all occasions to the supercargoes for the best information and advice' and decided on the option that he thought would do the least lasting damage to British long-term interests both in Canton and Peking (Amherst to Canning, 28 February 1817, in BL IOR G/12/197 (Reel 2) F 270).

Several other factors contributed to the rupture in the relationship between the British and Qing court arising out of the Amherst Embassy. The actions of a number of the mandarins contributed significantly to a breakdown of trust between themselves and the British, and with the Jiaqing emperor. Their duplicitous mishandling of the kowtow issue, which resulted in stressful and prolonged negotiations and false reports informing the emperor that Amherst had rehearsed the ceremony, incurred the emperor's anger when he learned the truth that Amherst was not prepared to kowtow. The mandarins' failure to keep the Jiaqing emperor accurately informed of the state of these negotiations as well as other matters, specifically the departure of the British ships after landing the ambassadorial party at Dagu and the conditions under which the embassy was suddenly transported to Yuanmingyuan, resulted in the demotion and punishment of several key mandarins. From the above, it is obvious that the mandarins were in an invidious position and were subject throughout the course of the negotiations to similar, if not greater, stresses and pressures to those faced by the British. This is illustrated by the succession of ever more senior mandarins consigned to take over the negotiations to ensure the recalcitrant British complied with the emperor's wishes. The instructions the mandarins had to follow allowed them little or no room to manoeuvre. Moreover, they were only too aware that failure to deliver acceptable outcomes would incur the emperor's displeasure, thus resulting in severe and humiliating punishments, which proved to be the case. The historians Backhouse and Bland (1914) concluded that the mandarins:

therefore lied to the Emperor about the [Amherst] Mission's attitude, and to the Mission about the emperor's, until at last, in order to extricate themselves, they were compelled to get rid of the foreigners at all costs. (p. 386) 
This assessment seems a fair summation. Once expelled, the embassy was a potent irritant and embarrassment to the Qing court as well as an unwelcome financial burden. The choice of the shortest route to Canton is evidence of the emperor's eagerness to rid his realm of the unwelcome visitors as soon as possible.

The British were guilty of a series of miscalculations both before and during the Amherst Embassy that, in retrospect, can be seen to have damaged their prospects of success on a range of issues.

First, the repeated assertion that the grandeur of the Macartney Embassy and deportment of its members had led the Chinese to view the British as an exceptional people and a special nation that would henceforth be handled outside the tributary system was flawed. This belief derived from Macartney's own reporting, whereby he sought to put the best possible gloss on his embassy's achievements despite its failure to achieve any of its goals. This view was kept alive and repeated by Barrow and Staunton to protect Macartney's legacy and their own involvement in the embassy, and in Staunton's case, the need to also guard his father's legacy.

Second, Macartney's success in negotiating an alternative ceremony and avoiding the kowtow in front of the Qianlong emperor led to the mistaken British assumption that this would also be acceptable to his son. This proved to be the final nail in the Amherst Embassy's coffin. Significantly, the further assumption that compromise resulting from negotiation was possible at the Qing court was born at the time of the Macartney Embassy and led to the erroneous belief that it would be possible for Amherst to enter into negotiations with the Qing court on British trade requests.

Third, after deferring a decision on another embassy to China for at least a decade, the decision to dispatch the Amherst Embassy was made in relative haste and based almost solely on Barrow's personal initiative. As the private correspondence over many years between Staunton and Barrow reveals, the real push behind Barrow's actions was his private objective to help enhance the career and reputation of Staunton with another embassy seen as the perfect vehicle. Barrow was deeply indebted to Staunton's father and Lord Macartney, and throughout his early career at the Admiralty was always on the lookout for ways to repay the debt by 
helping the young Staunton. ${ }^{13}$ Moreover, Barrow had based his arguments for another embassy on Staunton's reports from Canton-information that by 1816 was either out of date or no longer relevant. In addition, the British deliberately withheld notifying the Chinese of the impending embassy in order to limit the prospects of rejection and to present the Qing court with a fait accompli. The Chinese Government learned on 25 May 1816 of the expected arrival of the embassy, only 45 days before Amherst reached Chinese waters off Macao. Its arrival, shrouded in secrecy, aroused suspicion and concern for the Cantonese authorities. That the immediate pretext for the embassy, namely, the breakdown of trade relations in Canton between the Select Committee and the local authorities in 1814, had been resolved by the time Amherst arrived in China in July 1816 only complicated the issue.

Fourth, the belief that it was possible to negotiate with the Jiaqing emperor or his senior ministers on the attainment of British objectives proved false. Those dispatching the embassy knew that formidable obstacles lay in Amherst's path but thought that his personal charm, conciliatory manners and high aristocratic rank would facilitate a rapport with the Jiaqing emperor, ably assisted by Staunton's linguistic abilities and in-country knowledge. Access to the emperor based on an ability to communicate with him reflected Staunton's early belief that a knowledge of Manchu would assist him to converse with the Jiaqing emperor. Unfortunately, a diplomatic encounter conducive to negotiation on the basis of equality, or any negotiation for that matter, was always most unlikely if not, to the Chinese at least, inconceivable. The British received proof of this realisation after their expulsion from Yuanmingyuan when a copy of an imperial edict came to their attention (Morse, 1926/1966, vol. 3, pp. 295-297, Appendix 4). This edict set out the program planned in the event that the embassy had been received. It made clear that Amherst would not have had any opportunity to engage personally with the emperor during the three planned receptions. He was required to perform numerous kowtows; most of which were to take place out of the emperor's sight, at the far end of the reception hall and behind rows of other princes and mandarins (Morse, 1926/1966, vol. 3, pp. 295-297, Appendix 4). Moreover, the

13 In a letter dated 30 December 1805, Staunton requested his mother to thank 'Mr. Barrow' for his long letters and 'his endeavours to promote my interests' (Staunton Letters, Canton, 30 December 1805). 
emperor was scheduled to leave for Jehol less than two weeks later without any invitation extended to Amherst and his party to join him there, unlike the invitation offered to Macartney and his immediate retinue in 1793.

In attempting to establish a more stable trade relationship, the British were not offering the Qing court anything that it wanted or needed and, therefore, possessed no bargaining power from which to negotiate. From the Qing perspective, the 'Canton trade system' was working satisfactorily and no Chinese entity was seeking closer or expanded trading relations with the British. Of specific importance to the political context in which the Amherst Embassy was received by the Qing court was the deterioration in Anglo-Chinese relations at the time. The Jiaqing emperor regarded the British and their motives with a high degree of mistrust as a result of their two attempted occupations of Macao in 1802 and 1808, and the aggressive British naval actions in intercepting foreign shipping in Chinese territorial waters in 1814 . Staunton wrote later:

The Chinese had ... seen our troops more than once landed on their shores; and our naval forces had, during successive years, hovered about their coasts, with no hostile intention it is true, but in a way, which even the most unsuspicious nation might have considered in some degree questionable. (1822, p. 238)

Reflecting the emperor's concern, an imperial edict dated 11 January 1815 called for a strengthening of Chinese naval defence in the waters around Macao and the Pearl River Delta ('Imperial Edict, New Regulations to Control Foreign Merchants in Kwantung', 11 January 1815, in Fu, 1966, vol. 1, p. 395). The British occupations of Macao, Wang (2014) has argued, resulted in their being 'regarded as the most troublesome of Westerners' and raised serious alarm about Britain's imperial ambitions and expanding naval power (p. 248). The hardening of Qing attitudes at this time, Wang concluded, 'partly explains the emperor's rejection of the Amherst mission of 1816' (p. 248).

Davis, the 20-year-old interpreter in the embassy, destined to be the second governor of Hong Kong from 1844 to 1848, attributed the failure of the mission to the intrigues of the provincial Canton Government that had bribed the mandarins at Peking to prevent 'our obtaining any effectual access to the emperor' (Davis, 1841, p. 162). Citing their alarm at the 'sudden appearance' of the embassy only a year after Staunton had succeeded in getting his way with the local viceroy, Davis added: 
There could be no doubt whatever that every exertion had been made by that officer, through his connexions at Peking, to frustrate the success of the Embassy; and to this must be attributed the fruitless results of the mission, fully as much as to the difficulties of the ceremony. (p. 123)

Lamiot had written earlier in October 1807 of the obstacles facing any prospective European embassy to the Qing court. Amherst's pre-departure 'Notes' referred, somewhat prophetically, to Lamiot's conclusions on the role played by the mandarins:

If the Chinese admitted the injustice of their proceedings a necessary consequence would be the punishment in various degrees of a considerable number of persons, all of whom are therefore united against you and use any means of intrigue, deception and bribery to circumvent you. (Amherst's 'Notes' in BL IOR MSS EUR F 140/36)

The Chinese mandarins, in Davis's (1841) opinion, were susceptible to bribery due to their meagre salaries and the fact that, unlike their British equivalents, they did not possess hereditary titles or enjoy substantial private incomes (p. 162). He thought that the best way to gain Chinese respect was to act in 'a manner dramatically opposed to themselves' (p. 191).

Qing distrust of the British also included the Jiaqing emperor's concerns about both Staunton and Morrison in Canton and their subsequent inclusion in the Amherst Embassy as the second commissioner and senior interpreter, respectively. Moreover, the Qing court considered their linguistic abilities as dangerous, allowing them to communicate directly with native Chinese in those provinces that had recently experienced uprisings against the government. ${ }^{14}$ Amherst referred to Staunton's knowledge of the language in his official dispatch to George Canning, which 'was brought forward as furnishing the means of holding improper communications with traitorously disposed Chinese' (Amherst to Canning, 28 February 1817, in BL IOR G/12/197 (Reel 2) F 266). He added that the 'Chinese guard round the British quarters was ordered to be doubled' to prevent any 'traitorous correspondence between the Emperor's subjects, and the persons in the Embassy who were familiar

14 See Wang (2014, pp. 72-73) for the rise of the White Lotus movement in Shandong and Anhui province in the late Qianlong period. 
with the Chinese language' (Amherst to Canning, 28 February 1817, in BL IOR G/12/197 (Reel 2) F 266). These concerns would certainly have helped stiffen the resolve to ensure that Amherst complied fully with court ritual if he were to be granted an audience with the Jiaqing emperor. While the emperor was criticised by Amherst in his reporting, it was in fairly low key and measured terms. The real vilification of the emperor followed Amherst's return to England when the British press took up the cudgels.

Throughout their respective embassies, both Macartney and Amherst stayed within the boundaries and rules of European Westphalian diplomatic practice, even when it was obvious that it was proving totally ineffective in securing their official aims. Neither appeared to have an alternative plan to fall back on and neither gave any serious thought to the use of threats of coercion, although both Macartney and Amherst noted privately that British power could assist in the achievement of British goals. Macartney wrote:

If, indeed, the Chinese were provoked to interdict us their commerce, or do us any material injury, we certainly have the means easy enough of revenging ourselves, for a few frigates could in a few weeks destroy all their coast navigation and intercourse from the island of Hainan to the Gulf of Pei-chihli. (CranmerByng, 1962, p. 211)

He added:

The forts of the Bocca Tigris might be demolished by half a dozen broadsides, the river would be impassable without our permission, and the whole trade of Canton and its correspondencies annihilated in a season. The millions of people who subsist by it would be almost instantly reduced to hunger and insurrection. (p. 211)

Amherst stressed in his pre-departure notes that Britain acted as a responsible international citizen despite its power. If confronted by threats at the Qing court to either stop the British tea trade at Canton or, alternatively, to place it into the hands of the Americans, he was prepared to remind the court that:

A proof of our moderation is the restoration of Java and the Moluccas, while the conquest and the expulsion by our navy of every other European flag from the Eastern seas is proof of our power. The consequence of the Chinese breaking with England would be our immediate occupation of their valuable islands 
to the Eastward, particularly Formosa and Lieukieu, and the interruption of their Asiatic maritime trade. (Amherst, pencil notes on 'The objects of the Embassy' in BL IOR MSS EUR F 140/36)

Nevertheless, Amherst was guided in his actions by Barrow's advice that the diplomatic encounter should be conducted in a spirit of cordiality and equality but backed up with firmness, dignity and patience. Ultimately, the Amherst Embassy's reception proved the futility of engaging in any future diplomatic negotiation with the Qing Government to achieve British commercial aims in China. Morrison had expressed a view in early 1815 that the Chinese Government would never acquiesce to the demands of a few foreign merchants until forced to do so by an enemy 'nearer [to] their gates' (Morrison to Staunton, 10 January 1815, in Morrison, 1839, p. 425). Barrow (1819) commented that it was clear that the emperor, or 'Supreme Sovereign of the earth', had little regard for the truth and that he wished to decline any further diplomatic intercourse with Britain (p. 86). He added that, although trading conditions at Canton had improved since the embassy, the Chinese were nevertheless:

busily engaged in building forts on every accessible part of the coast from the Bocca Tigris to the Pei-ho, His Imperial Majesty's ministers being under great apprehension that their treatment of Lord Amherst may be yet visited upon them by a less pacific mission than the last. (p. 86)

A revised British assessment of China, framed by the failure of the Amherst mission, arose from the diplomatic ashes. The publisher John Murray wrote to Lord Byron with his view on the reception of the Amherst Embassy at Yuanmingyuan:

I wish I could shew you extracts from the Peking Gazette in which the Chinese speak of our Embassy—such contempt—we have got near to them by means of Nepaul [sic] and before I die I hope we shall have a war with them. (Nicholson, 2007, p. 207) (15 $^{15}$

It was clear that the Chinese Government would never voluntarily receive an ambassador as a means of redressing British grievances. China and its culture had nothing to offer the West apart from tea and a potentially large commercial market for British goods based on the fact that the Chinese are important because they are numerous' (Slade, 1830, p. iii). The final

15 I thank Professor Tim Barrett for bringing this reference to my attention. 
word on the Anglo-Chinese diplomatic encounter was proclaimed by the Jiaqing emperor who informed the Prince Regent in a letter dated 11 September 1816:

There will be no occasion hereafter for you to send an ambassador from so great a distance, and to give him the trouble of passing over mountains and crossing the ocean. If you do but pour out the heart in dutiful obedience, it is by no means necessary, at any stated time, to come to the celestial presence, ere it be pronounced that you turn towards the transforming influences which emanate from this empire. (Jiaqing emperor to the Prince Regent in Asiatic Journal, 1819, vol. 8, p. 342)

\section{Amherst told Canning:}

Judging from what has occurred in the instance of the present Embassy, and of the Embassy from Russia in 1805, I conceive that no foreign Embassador is likely to be admitted into the presence of the Emperor Kia-King, unless he agrees to perform, to its full extent, the Tartar Ceremony of the Ko-tou. Perhaps the present emperor, whose reign has been frequently and very lately disturbed by insurrections of his subjects, may less readily dispense with outward forms of respect than his Father, whose reign was long and victorious, and who, being firm in the possession of real power and authority, might attach less consequence to any show of external homage. (Amherst to Canning, 21 April 1817, in BL IOR G/12/197 (Reel 2) F 377)

Amherst thought that 'the precipitate and unwarranted rejection of the Embassy from the Palace Gates has left an injury to repair' (Amherst to Canning, 21 April 1817, in BL IOR G/12/197 (Reel 2) F 378). He described his reception at the court as one of:

hurry and confusion, of irregularity and disorder, of insult, inhumanity, and almost of personal violence, sufficient to give to the court of the emperor Kia-King the manners, character, and appearance of the roving-camp of a Tartar Horde. (Amherst to Canning, 8 March 1817, in BL IOR G/12/197 (Reel 2) F 285)

The Chinese were aware that the rules of diplomatic hospitality had been violated and were possibly apprehensive of 'the manner in which the transaction will be viewed in Great Britain' (Amherst to Canning, 21 April 1817, in BL IOR G/12/197 (Reel 2) F 379). Evidence of this, Amherst thought, was found in the 'honourable treatment of the Embassy 
on its' [sic] return' to Canton, and for the emperor's proposal for a partial exchange of presents as 'a wish for reparation in the only way which the pride of the Emperor would allow' (Amherst to Canning, 21 April 1817, in BL IOR G/12/197 (Reel 2) F 379). He requested that it be made known to the Prince Regent and his government, and to the Company:

whose interests have been committed principally to my care, that I have executed my trust with fidelity, and that my want of success is not to be attributed to want either of zeal or discretion in the performance of my duty, [and] I shall be amply rewarded for the vexation and disappointment, for the difficulty and danger, without which it has not been my lot to execute this service. (Amherst to Canning, 21 April 1817, in BL IOR G/12/197 (Reel 2) F 380)

Amherst arrived back in England on 16 August 1817. The final line in his diary noted with happiness that he 'once more [had] the satisfaction of setting foot in old England' (as quoted in Ritchie, 1894, p. 20). ${ }^{16}$ Having signed off his commission in late 1817, Amherst, unlike Staunton and Ellis, chose to avoid any public comment on China or Anglo-Chinese trade relations. Rather, he retired to his estate, 'Montreal', where he pursued a busy life commuting between Sevenoaks and London until called on to replace Lord Moira as governor-general of Bengal in 1823.

16 Ritchie's (1894) book includes several references to Amherst's handwritten diary at the time of his embassy to China. Peyrefitte (1992, pp. 513, 598) also refers to a 'handwritten journal' held in the private collection of Mr Michael Galvin of Santa Barbara, California. Attempts by the author to locate his diary have been unsuccessful. 
This text is taken from Britain's Second Embassy to China: Lord Amherst's 'Special Mission' to the Jiaqing Emperor in 1816, by Caroline Stevenson, published 2021 by ANU Press, The Australian National University,

Canberra, Australia.

doi.org/10.22459/BSEC.2020.12 